4) G. H. Morrison, H. Freiser (田中元治, 金森 俉訳)：“溶媒抽出分析法”, p. 124 (1959), (丸善).

$$
\text { 它 }
$$

Extraction of copper-thiocyanate complex by tributylphosphate (TBP) and its application to copper determination in aluminum alloy. (Solvent extraction in analytical chemistry. VI) Nobuo Tajima, Moriji Kurobe and Hiroaki Terada (Toyoda Automatic Loom Works, Ltd.)

The effect of concentration of thiocyanate and $\mathrm{pH}$ on the TBP extraction of copper-thiocyanate complex was investigated, and it was found that above $99.9 \%$ extraction was effectuated in the concentration of $0.2 \sim 1.2 M$ of thiocyanate and with $\mathrm{pH} 1 \sim 7$. Also, the percentage recoveries by the ammonia reextraction of the solventextracted copper indicated that thiocyanate concentration and $\mathrm{pH}$ had marked influences on the copper recovery. Namely, an increase in the thicyanate concentration or a lowering of $\mathrm{pH}$ was followed by a considerable decrease in the per cent recovery. However, using of TBP-benzine $(1: 1)$ as a solvent caused an increase in the reextraction rate and a recovery rate above $99 \%$ in the ammonia reextraction was obtained with $0.2 \sim$ $0.8 M$ thiocyanate under the $\mathrm{pH} 1 \sim 5$.

The method was applied for separation of copper in aluminum alloy followed by the determination of copper by thiosulfate titration. Good result was obtained for $1 \sim 4 \%$ copper.

(Received June 10, 1961)

\title{
フェロニオブ, 含ニオブスラッグ中のニオブの 交流ポーラログラフ法による迅速定目法
}

斎藤謙, 武内 次夫*

最近，工業原料として重要性を増加したフェロニオブ，含ニオブスラッグの中のニオブの迅速定量法 研究した. これらの 2 種類の試料では本定量法に最も妨害を与えるバナジウムを含んでいなかったの で, 試料をフッ化水素酸と硫酸に溶解し, 硫酸を白煙の状態に加熱してフッ化水素酸を追い出したのち, 濃塩酸で希积し，濃塩酸を支持電解質とする交流ポーラログラムを記録し，そのピークの高さから二オ ブを簡易迅速に定量するととができた．分析值は著者らが既に報告した有機溶媒抽出法を併用する重量 分析法による結果とほぼ一致して打り，分析所要時間は約 1 時間であった.

\section{1 緒言}

相当量のニオブの定量法としては重量法が主として行 なわれているが，方法の性質上長時間を要する。一方， 容量法は重量法に比較すると迅速ではあるが，いろいる の困難な問題1)2) がある.

著者らはフェロニオブ, 含ニオブスラッグなどのニオ ブを主成分 $(60 \sim 70 \%)$ とし，比較的他元素を少量しか 含まない試料について，そのなかのニオブを有機溶媒抽 出法にようて分離する操作を行なうことなく, 含ニオブ スラッグの場合はそのまま, フェロニオブの場合は塩化 第一スズにより鉄を還元したのち，交流ポーラログラム をとるという迅速簡便な方法によって定量し, ほぼ満足 すべき結果を得た。

* 名古屋大学工学部工業分析化学教窒 : 名古屋市千種 区不老町

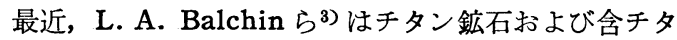
ン顔料のなかの比較的少量（約 $0.5 \%$ 以下）のニオブを 有機溶媒抽出法で分離してのち, 交流ポーラログラフ法 によって定量を行なっていることを知ったが，著者らの 実験は対象試料の相違によりポーラログラフにかける前 の予備操作が大いに異なり, はるかに簡易迅速な方法で ある・

\section{2 試薬および装置}

\section{$2 \cdot 1$ 試 薄}

ニオブ標準溶液 : 横沢化学製特級五酸化ニオブ(99\%) を再沈殿法により精製した.とのものを分光分析によっ て調べた結果, タンタルはほとんど慧められなかった。 この精製した五酸化ニオブの $0.1430 \mathrm{~g}$ をはかりとり, フッ化水素酸約 $3 \mathrm{ml}$ に溶解し, 次に硫酸 $1 \mathrm{ml}$ を加え てほとんど乾固近くまで加熱蒸発したのち, 濃塩酸を加 えてメスフラスコを用いて $100 \mathrm{ml}$ にうすめた. ての溶 
液の $1 \mathrm{~m} l$ は $1.0 \mathrm{mg}$ のニオブを含む.

フッ化水素酸, 塩酸, 硫酸, 塩化第一スズ : いずれも 特級試薬を使用した.

混酸：フッ化水素酸につき $10 M$, 硫酸につき $6 M$ の 溶液.

逆抽出液 : $2 M$ のフッ化アンモニウムの溶液.

メチルイソブチルケトン: 特級試薬, 使用前に上記の 混酸とふりまぜておく・

妨害イオンの影響を検討するために用いた各種金属の 水溶液は鉄, マンガン, チタン, ニッヶル, クロムはお の打の塩化物の塩酸酸性溶液とし, モリブデンとバナシ ウムはモリブデン酸アンモニウム扣よびバナジン酸アン モニウムの硫酸酸性溶液とした. 各金属イオンの濃度は $10^{-1} M$ とした.

その他の試薬も特級品を使用した.

\section{$2 \cdot 2$ 装}

ポーラログラフ：柳本製ペン記録式交直ポーラログラ

フ P A-101 型を使用した.

実験はすべて $25 \pm 1^{\circ} \mathrm{C}$ の恒温ソウ中で行ない，アル カリ性ピロガロール溶液で精製した窒素ガスをさらに濃 塩酸のなかを通し，てれを電解瓶中に通して溶存酸素を 除いた. 滴下水銀電極の特性は $12 N$ 塩酸の溶液中 -0.3 $\mathrm{V}$ (対水銀池) で $m=1.52 \mathrm{mg} \cdot \mathrm{sec}^{-1}, t=3.75 \mathrm{sec}$, $m^{2 / 3} t^{1 / 6}=1.65 \mathrm{mg}^{2 / 3} \cdot \mathrm{sec}^{-1 / 2}$ であった。

\section{3 基礎実験}

\section{$3 \cdot 1$ ニオブの交流ポーラログラム}

ニオブのポーラログラフ分析に関しては直流ポーラロ グラフが多く, 支持電解質溶液としてリンゴ酸, クエン 酸などの有機酸》を用いたもの，塩酸らを用いたもの， 硫酸をを用いたものなどが報告されている．著者らは濃 塩酸を支持電解質とする交流ポーラログラフ法を検討 乙，試料中のニオブの含有量が高いので比較的ニオブの 濃度の高い処 $\left(10^{-3} M\right.$ 付近) において実験を行なった.

まず $18.6 \mathrm{mg}$ のニオブを含む標準液 $18.6 \mathrm{ml}$ をとり， $100 \mathrm{~m} l$ のメスフラスコに移し, 濃塩酸を用いて 標線ま でうすめ, その一部を電解瓶にとり $25 \pm 1^{\circ} \mathrm{C}$ の恒温槽 に約 10 分間浸したのち, $2 \cdot 2$ に記したような条件で, $-0.05 \sim-0.70 \mathrm{~V}$ (対水銀池) の間の交流ポーラログラ ムを画かせた. その結果を Fig. 1 亿示した.

Fig. 1 に見られるように, $-0.27 \mathrm{~V}$ と $-0.50 \mathrm{~V}$ と に二つのピークを与えるが， $-0.27 \mathrm{~V}$ のピークの方がベ 一スラインもほとえど水平であり，また非常にピーク自 身も安定であり，再現性にも富むのでこれを定量に使用 することにした．とのピークは $\mathrm{Nb}^{5+\sim 4+}$ 光の還元波で あると考元られ，次の $-0.50 \mathrm{~V}$ のピークは $\mathrm{Nb}^{4+} \sim^{+}$ えの還元波であると考元られた。後者のピークは形も乱 れ勝ちであり, ベースラインも不安定で定量には不適当

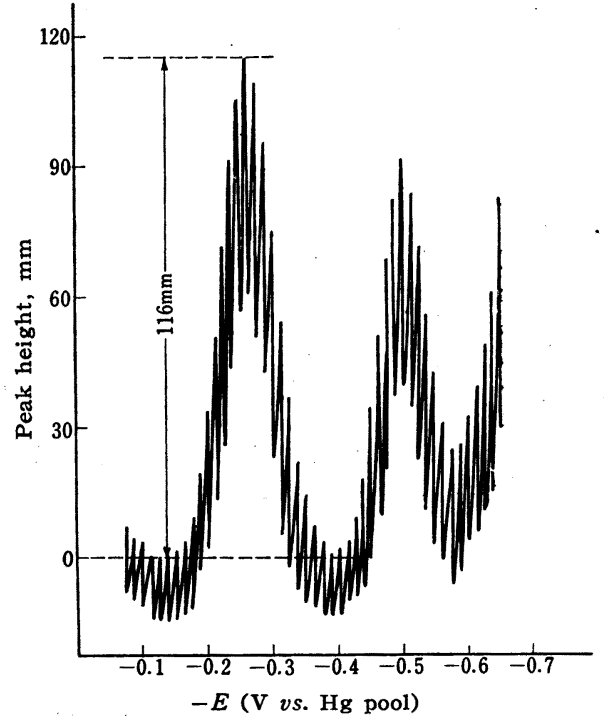

Fig. 1 A. C. polarogram of niobium in $12 \mathrm{~N}$ $\mathrm{HCl}$

$\mathrm{Nb}: 18.6 \mathrm{mg} / 100 \mathrm{ml} \quad$ Sensitivity $: 4.0 \mu \mho / \mathrm{mm}$

であると考えられた.

なお，試料溶液中の窒素を通す時間が短くて酸素の除 去が不十分の時には，ピークの形が著しく乱れてピーク の高さを測定することができなくなるから，前に述べた ように，5分間ほど通して酸素をよく除去しておく必要 があった。

\section{$3 \cdot 2$ 塩酸浱度の影響}

3.1 と同じ量のニオブをとり, 同じ条件で塩酸の濃度 だけを変化させて実験を行なった. 塩酸の濃度は $11.5 \mathrm{~N}$ までは $12 N$ の場合と同じピークの高さを得たが，それ， よりも塭酸がうすくなると第 1 のピークは次第に高さを 減少し， $3 N$ になると全くピークを示さなかった. また， 第 2 のピークの方む塩酸がうすくなるにつれてピークが 消失した. その様子を Fig. 2 に示した. 以上の実験の. 結果から以後ニオブの定量実験は $12 N$ の塩酸で行なう ことにした.

\section{$3 \cdot 3$ 直流ポーラログラムとの比較}

3.1 と同一の条件で直流ポーラログラムを画かせて交 流のそれと比較して見た. その結果を Fig. 3 . 亿示し た.

交流の場合と比較して見ると直流の方は波形が良好で なく, 波形の測定がむずかしく，かつ感度も約 $1 / 3$ 飞减 少した.すなおち, 交流ポーラログラムの方が直流に比 べてすぐれているといえる. 


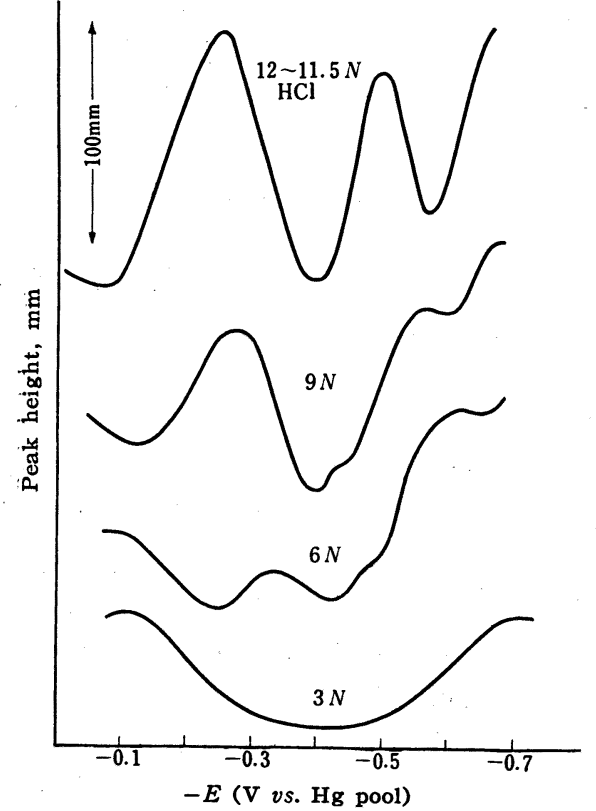

Fig. 2 Relation between $\mathrm{HCl}$ concentration and peak height for $\mathrm{Nb}$

$\mathrm{Nb}: 18.6 \mathrm{mg} / 100 \mathrm{ml}$ Sensitivity $: 4.0 \mu \mho / \mathrm{mm}$

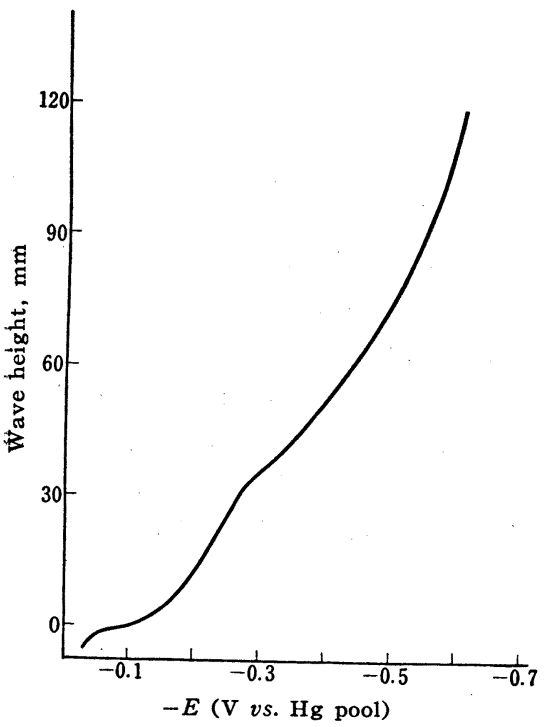

Fig. 3 D. C. polarogram of niobium in $12 \mathrm{~N}$ $\mathrm{HCl}$

$\mathrm{Nb}: 18.6 \mathrm{mg} / 100 \mathrm{~m} l$

Sensitiviuy : $0.080 \mu \mathrm{A} / \mathrm{mm} \times 100 \mathrm{mV} / \mathrm{mm}$

\section{$3 \cdot 4$ ニオブの検量線の作製}

ニオブとして 0〜28.0 mg を含むように, 標準溶液を $100 \mathrm{ml}$ の乾燥したメスフラスコにとり，濃塩酸を加え
て標線までうすめ, その一部を電解瓶に移し, $3 \cdot 1$ に記 した条件で交流ポーラログラムを画かせ，Fig. 1 に示 したようにして $-0.27 \mathrm{~V}$ (対水銀池) のピークの高さを 測り，ニオブの量とピークの高さとの関係をグラフに画 くことにより検量線をつくった. ニオブの $9.29 \mathrm{mg} / 100$ $\mathrm{m} l$ が $1 \times 10^{-3} M$ の濃度にあたり, その場合のピークの 高さは感度 $8.0 \mu \mho / \mathrm{mm}$ のときは $33 \mathrm{~mm}, 4.0 \mu \mho / \mathrm{mm}$ のときは $58 \mathrm{~mm}$ であり,この際の繰り返し精度は $3 \sim 6$

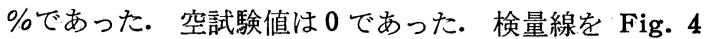
に示した.

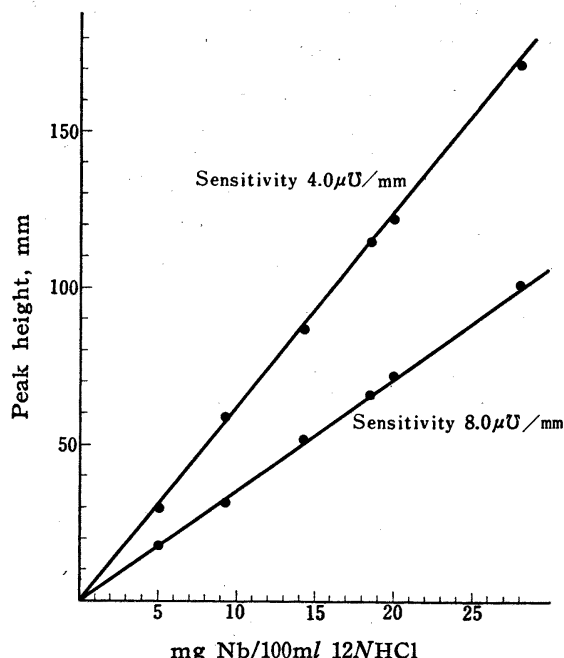

Fig. 4 Relation between concentration of niobium and peak height

\section{$3 \cdot 5$ 共存元素の影響}

試料中に共存する元素として鉄, マンガン, チタン, ニッケル, クロム, バナジウム，モリブデンをえらんで その影響をしらべた。

各元素の $10.0 \mathrm{mg}$ を含む溶液(各元素の溶液は 2.1 に 記した方法でつくったもの）をニオブ $10.0 \mathrm{mg}$ を含む 標準溶液とともに白金ざらにとり，いったん蒸発乾固し てのち, フッ化水素酸 $3 \mathrm{ml}$ と硫酸 $1 \mathrm{ml}$ を加えて再び加 熱し，ほとえど乾固近くまで濃縮してのち濃塩酸を加え て析出した塩類をとかし, $100 \mathrm{ml}$ のメスフラスコを用い て一定容積とし，その一部をとってポーラログラムを画 かせた。

その結果, マンガン, チタン, ニッケル, クロム, モ リブデンは影響がなかった。

鉄は塩化第一スズを加えて存在している第二鉄塩を第 一鉄塩に還元して打けば，支障なく実験を行なうことが 
できた.すなわち，フェロニオブのような鉄の含有量が 約 $50 \%$ 程度の試料では, 鉄を分離することなくニオブ を定量することができることがわかった.なお, 鉄の量 が溶液 $100 \mathrm{ml}$ のなかで $2 \mathrm{mg}$ 程度の少量の場合は還元 を行なわなくてもよいことがわかった。

バナジウムは濃塩酸酸性でニオブと同じようにー0.27 V、にピークを与え, その感度もほぼニオブと同じ位であ る. 今感度 $4.0 \mu \mho / \mathrm{mm}$ でニオブを測定する場合, ポー ラログラムのピークの高さの測定の誤差の限界を $2 \mathrm{~mm}$ とすると, バナジウムはほぼニオブに匹敵する感度を有 することからみて, このピークの高さを与えるバナジウ ムの量は $0.3 \mathrm{mg} / 100 \mathrm{ml}$ となる. このことからバナジ ウムの最低許容量は $0.3 \mathrm{mg} / 100 \mathrm{ml}$ であるといえる. なお，ニオブの定量におけるバナジウムの影響について は目下研究中であり, 追って発表の予定である.

それゆえ許容量以上のバナジウムの存在する場合は, 溶媒抽出によって分離してからニオブの定量を行なう必 要があるが, 今回の試料の場合は, 定性分析の結果バナ ジウムは $0.02 \%$ 以下しか含まれていないので, 特別除 去の操作は必要がなかった.

タンタルに関しては, Balcher らろが既にのべている ようにピークを与えなかった。

4 フェロニオブおよび含タンタルスラッグ 中の二オブの定量

\section{$4 \cdot 1$ フェロニオブ中のニオブの定量方法}

細粉した試料 $40 \mathrm{mg}$ 程度をはかりとって白金ざらに移 乙, フッ化水素酸 $3 \mathrm{~m} l$ と濃硫酸 $1 \mathrm{~m} l$ とを用いて砂ざら 上で静かに加熱して溶かし，ほとえど乾固近くまで濃縮 する.濃㙉酸を加えて白金ざらの内容物を溶かし, 乾燥 した $100 \mathrm{~m} l$ のメスフラスコに移し, 塭化第一スズ溶液 $(1 / 4 M) 0.5 \mathrm{ml}$ を加えふりまぜて第二鉄塩を第一鉄塩 に還元したのち, さらに濃塩酸を追加して標線までうす め, 以下 $3 \cdot 1$ に記した方法で交流ポーラログラムをとり， あらかじめ作ってある検量線からニオブの量を求める. 定性分析》の結果* バナジウムの存在がみとめられなか ったので $(\mathrm{V}$ 含有量 : $<0.02 \%)$, 有機溶媒によるニオブ の抽出分離を行なわなかった.

\section{$4 \cdot 2$ 含タンタルスラッグ中のニオブの定量方法}

定量方法は $4 \cdot 1$ に準じた.ただし，この試料は鉄の含 有量が非常に少ない $(<0.1 \%)$ ので塩化第一スズによる

* 定性分析の場合，バナジウムの検出限界は $10 \gamma / 30$ $\mathrm{m} l$ であり, 今試料 $50 \mathrm{mg}$ をとり $30 \mathrm{ml}$ にして呈 色反応をみとめなかったので，試料中のバナジウム の含量は $0.02 \%$ 以下であった。
鉄の還元操作を行なう必要がなかった.

なお，この試料はナイジェリアの鉱石（概略の組成と して，五酸化ニオブ 60〜70\%，五酸化タンタル 6〜7\%， 酸化鉄 15〜20\%，酸化チタン 1 2\%, 酸化スズ $2 \%$, その他)からタンタルを採取した残りのスラッグであり， バナジウムは定性分析》の結果存在がみとめられなかっ たので，有機溶媒によるニオブの抽出分離を行なうこと なく定量を行なった.

\section{$4 \cdot 3$ ニオブの重量分析法}

ポーラログラフ法との比較のために, 両試料について 有機溶媒抽出法を併用する重量分析を行なった。方法は 著者らが先に行なった金属チタン製造工程中の中間製品 の分析方法(3) に従ったが，次にその概略を記す。

試料約 $0.1 \mathrm{~g}$ をはかりり, フッ化水素酸 $5 \mathrm{ml}$ と硫 酸 $1 \mathrm{~m} l$ とを用いて白金ざらのなかでとかし，混酸を用い てポリエチレン製の分液ロートに移し，メチルイソブチ ルケトン $30 \mathrm{ml}$ ずつ 3 回を用いてニオブを抽出し，これ を混酸で洗浄してのち，2M のフッ化アンモニウム溶液 $80 \sim 90 \mathrm{~m} l$ で逆抽出し, これを蒸発濃縮してから過塩素: 酸を加えて白煙を発生させてニオブを洗殿析出させ, こ れを口過, 洗浄, 強熱して五酸化ニオブとしてひょう量 する.

\section{$4 \cdot 4$ 定量結果}

$4 \cdot 1$ 打よび $4 \cdot 3$ にのべた方法に従ってフェロニオブの 中のニオブの定量を行ない, その結果を Table I に示: した. また，4.2 および4.3にのべた方法に従って含二 オブスラッグの中のニオブの定量を行ない，その結果を Table II に示した.

Table I, II に示すように, 交流ポーラログラフ法の 方が重量分析法に比較してやや低い值を得たが，ほぼ一 致した值であった。重量分析法が高い值であったのは, 沈殿のなかに微量のタンタルを含むからではないかと思. われる。

Table I Determination of niobium in ferro-niobium

\begin{tabular}{|c|c|c|c|c|c|c|}
\hline \multicolumn{4}{|c|}{ A. C. polarographic method } & & \multirow{2}{*}{\multicolumn{2}{|c|}{$\begin{array}{c}\begin{array}{c}\text { Gravimetric } \\
\text { method }\end{array} \\
\text { Niobium found }\end{array}$}} \\
\hline \multirow{2}{*}{$\begin{array}{l}\text { Weight } \\
\text { of sample } \\
\text { taken } \\
\text { (mg) }\end{array}$} & \multirow{2}{*}{$\begin{array}{l}\text { Peak height } \\
\text { sensitivity } \\
(4.0 \mu \nabla / \mathrm{mm}) \\
(\mathrm{mm})\end{array}$} & \multicolumn{3}{|c|}{ Niobium found } & & \\
\hline & & $(\mathrm{mg})$ & $(\%)$ & $\begin{array}{c}\text { mean } \\
(\%)\end{array}$ & $(\%)$ & $\begin{array}{c}\text { mean } \\
(\%)\end{array}$ \\
\hline $\begin{array}{l}40.0 \\
39.0 \\
34.2 \\
34.2 \\
28.0\end{array}$ & $\begin{array}{l}166 \\
154 \\
145 \\
144 \\
120\end{array}$ & $\begin{array}{l}27.2 \\
26.4 \\
23.4 \\
23.2 \\
19.2\end{array}$ & $\begin{array}{l}68.0 \\
67.7 \\
68.4 \\
68.0 \\
68.6\end{array}$ & 68.1 & $\left.\begin{array}{l}68.5 \\
68.4 \\
68.1\end{array}\right\}$ & 68.4 \\
\hline
\end{tabular}


Table II Determination of niobium in slag containing niobium

\begin{tabular}{|c|c|c|c|c|c|c|}
\hline \multicolumn{4}{|c|}{ A. C. polarographic method } & & \multirow{2}{*}{\multicolumn{2}{|c|}{$\begin{array}{c}\text { Gravimetric } \\
\text { method } \\
\text { Niobium foune }\end{array}$}} \\
\hline \multirow{2}{*}{$\begin{array}{l}\text { Weight } \\
\text { of sample } \\
\text { taken } \\
(\mathrm{mg})\end{array}$} & \multirow{2}{*}{$\begin{array}{l}\text { Peak height } \\
\text { sensitivity } \\
(4.0 \mu \mho / \mathrm{mm}) \\
(\mathrm{mm})\end{array}$} & \multicolumn{3}{|c|}{ Niobium found } & & \\
\hline & & (mg) & $(\%)$ & $\underset{(\%)}{\operatorname{mean}}$ & $(\%)$ & $\underset{(\%)}{\operatorname{mean}}$ \\
\hline $\begin{array}{l}31.6 \\
42.4 \\
28.0 \\
29.4 \\
38.0\end{array}$ & $\begin{array}{l}125 \\
167 \\
110 \\
116 \\
152\end{array}$ & $\begin{array}{l}20.6 \\
27.3 \\
18.1 \\
18.9 \\
24.4\end{array}$ & $\begin{array}{l}65.0 \\
64.3 \\
64.6 \\
64.1 \\
64.2\end{array}$ & 64.4 & $\left.\begin{array}{l}64.9 \\
65.2 \\
64.7\end{array}\right\}$ & 64.9 \\
\hline
\end{tabular}

\section{5 分析所要時間}

交流ポーラログラフ法によるフェロニオブおよび含ニ オブスラッグの分析所要時間を示すと Table III のよ うになる.すなわち, 全所要時間は約 57 分であり, 迅 速分析の立場から重量分析法に比較して満足できるもの である・

Table III Analytical time required (Example)

\begin{tabular}{lc}
\hline & Time (min) \\
Sample weighing & 1 \\
Decomposition & 5 \\
Heating with $\mathrm{H}_{2} \mathrm{SO}_{4}$ (White fume) & 20 \\
Cooling, dilution (in measuring flask) & 5 \\
In a thermostat & 10 \\
$\mathrm{~N}_{2}$ gas saturation & 5 \\
A. C. polarography & 10 \\
Calculation & 1 \\
Total & 57 \\
\hline
\end{tabular}

\section{5 考察}

ニオブを主成分とするフェロニオブおよび含ニオブス ラッグ中のニオブの定量を，有機溶媒抽出による分離を 行なわないで酸にとかしたのち，すぐに交流ポーラログ ラフにかける方法によって行なった. 結果は重量分析法 にほぼ一致し, また所要時間も 1 時間以内であり, 迅速 分析として満足すべきものと思われた。

本方法はタンタルの影響のないことが特長であるが,
バナジウムの妨害をうけるので, もし相当量のバナジウ ムを含む試料の場合には，メチルイソブチルケトンなど の有機溶媒によって二オブを分離してから交流ポーラロ グラフにか情る必要があると思われる。

最後に，実験の一部を援助された仁科技官に感謝する。 （昭和 36 年 4 月, 日本化学会第 14 年会に扣いて発表）

$$
\text { 交献 }
$$

1) Yoshinaga Oka, Masatoshi Miyamoto: Science Reports Research Insts, Tohoku Univ., 1, 115 (1949).

2) 岡 好良, 宫本正俊：日化，69，133（1948).

3) L. A. Balcher, D. I. Williams : Analyst, 85, 503 (1960).

4) D. J. Ferrett, G. W. C. Milner : J. Chem. Soc., 1956, 1186.

5) P. J. Elving, E. C. Olsen : Anal. Chem., 28, 338 (1956).

6) E. I.Krylov, V. S. Kolevatova : Zavodskaya Lab., 21, 911 (1955).

7）俵 国一監修：“鉄鋼化学分析全書”, 上巻, p. 72 (1951), (日刊工業新聞).

8）斎藤 謙, 武内次夫：本誌, 投稿中.

$$
\text { 陉 }
$$

Rapid determination of niobium in ferroniobium and slag containing niobium by A. C. polarography. Ken SaITo and Tsugio TAKEUCH (Institute of Techno-analytical Chemistry, Faculty of Engineering, Nagoya University)

A simple and rapid method for the determination of niobium in ferro-niobium and $\mathrm{Nb}$-containing slag by A. C. polarography excluding an extraction with organic solvent has been studied.

Samples were dissolved in hydrofluoric acid and evaporated almost to dryness, and redissolved into concentrated hydrochloric acid. In the case of ferro-niobium, ferric ion was reduced to ferrous ion by adding stannous chloride. After the solutions were diluted to a definite volume with concentrated hydrochloric acid, niobium was determined by A. C. polarography.

The analytical results were comparable with those obtained by the gravimetric method with satisfactory agreements.

The time required for an analysis was about an hour.

(Received May 9, 1961) 